\title{
Pengaruh Disiplin Kerja Kepala Sekolah dan Motivasi Terhadap Kinerja Guru Sekolah Dasar Negeri
}

\author{
Yulia $^{1}$, Nur Ahyani ${ }^{2}$, Ratu Wardarita ${ }^{2^{*}}$ \\ ${ }^{1}$ SD Negeri 1 Penukal \\ ${ }^{2}$ Program Pasca Sarjana Universitas PGRI Palembang \\ Jl. Jendral A Yani No 13 Ulu Kota Palembang 30263 Sumatera Selatan
}

*Email: ratuwardarita@yahoo.com

Naskah diterima 10 Agustus 2021, Revisi 15 September 2021, Terbit 29 Oktober 2021

\begin{abstract}
DOI: doi.org/10.21107/pamator.v14i2.11478

This research aimed to study and to test the effect of the principal work discipline (variable X1) on teacher performance (variable $Y$ ), the effect of the work motivation (variable X2) on teacher performance (variable $Y$ ) and the effect of the principal's work discipline (variable X1) and motivation work (variable X2) together on the performance of teachers (variable $Y$ ). The method used of this research was survey research design. Based on the results of the data analysis that had been carried out the influence of the principal discipline variable and work motivation variable on the teacher performance variable was $98.3 \%$, this value implied that the principal of the discipline variable and work motivation variable jointly affect of the teacher's performance variable by $98.3 \%$, while the remains was influenced by variables that were not examined. These results indicated that there were an influence of the principal's work discipline variable and work motivation variable on the teacher's performance variable, both individually or together.
\end{abstract}

Key words: principal's work discipline, work motivation, teacher performance

\section{PENDAHULUAN}

Perkembangan zaman yang semakin maju pada dekade 2020-an ini menuntut adanya Sumber Daya Manusia (SDM) yang berkualitas. Sumber daya manusia yang berkualitas merupakan modal utama untuk mencapai tujuan pembangunan. Salah satu cara untuk meningkatkan kualitas SDM tersebut adalah Pendidikan.Undang-undang Nomor 20 Tahun 2003 tentang Sistem Pendidikan Nasional Bab I Pasal 1 menyatakan Pendidikan adalah usaha sadar dan terencana untuk mewujudkan suasana belajar dan proses pembelajaran agar peserta didik secara aktif mengembangkan potensi dirinya untuk memiliki kekuatan spiritual keagamaan, pengendalian diri, kepribadiaan, kecerdasan, akhlak mulia, serta keterampilan yang diperlukan dirinya, masyarakat, bangsa dan negara.

Menurut Rohiat (2019) permasalahan pendidikan yang dihadapi oleh bangsa Indonesia adalah rendahnya mutu pendidikan pada setiap jenjang dan satuan pendidikan, khususnya pendidikan dasar dan menengah. Berbagai usaha telah dilakukan meningkatkan mutu pendidikan nasional, misalnya pengembangan kurikulum nasional lokal, peningkatan kompetensi guru melalui pelatihan, pengadaan buku dan alat pelajaran, pengadaan dan perbaikan sarana dan prasarana pendidikan,dan peningkatan mutu manajemen sekolah. Namun demikian, berbagai indikator mutu pendidikan belum menunjukkan peningkatan yang cukup mengembirakan sebaliknya sebagian lainnya masih memprihatinkan. Dari berbagai pengamatan dan analisis, ada tiga faktor yang menyebabkan rendahnya mutu pendidikan nasional. Faktor yang pertama kebijakan dan penyelenggaraan pendidikan nasional yang mengunakan pendekatan education product in function atau input-output analysis tidak dilaksanakan secara konsekuen.

Pendekatan ini melihat bahwa lembaga pendidikan berfungsi sebagai pusat produksi yangapabila dipenuhi input yang diperlukan dalam kegiatan produksi tersebut,lembaga ini akan menghasilkan output yang dikehendaki. Pendekatan ini juga menganggap bahwa apabila input pendidikan seperti guru, buku, media pembelajaran dan sarana dan 
prasarana pendidikan lainnya dipenuhi, mutu pendidikan (output) secara otomatis akan meningkat. Pendapat Mulyasa (2011) para guru akan bekerja dengan sungguh-sungguh apabila memiliki motivasi yang tinggi. Apabila memiliki motivasi yang positif, ia akan memperlihatkan minat, mempunyai perhatian, dan ingin ikut serta dalam suatu tugas atau kegiatan. Sesuai dengan pendapat tersebut, guru yang masih kurang berhasil dalam mengajar dikarenakan mereka kurang termotivasi untuk mengajar sehingga berdampak terhadap menurunnya produktivitas atau kinerja guru. Untuk itu diperlukan motivator untuk memotivasi para guru meningkatkan kinerjanya.

Menurut Fatah dalam Tobari et al., (2020) bahwa sekolah sebagai lembaga atau institusi pendidikan yang merupakan wadah tempat proses pendidikan dilakukan, memiliki sistem yang kompleks dan dinamis. Sekolah bukan hanya sekedar tempat berkumpul guru dan murid, melainkan berada dalam satu tatanan sistem yang rumit dan saling berkaitan oleh karena itu sekolah dipandang sebagai suatu organisasi yang membutuhkan pengelolaan. Kegiatan inti dari organisasi sekolah adalah untuk mengelola sumber daya manusia (SDM) yang diharapkan guna untuk menghasilkan lulusan berkualitas, sesuai dengan tuntutan kebutuhan masyarakat serta dapat memberikan konstribusi pembangunan bangsa dan negara. Menurut Susanto dalam Juniarti et al, (2020) Kepala Sekolah dituntut untuk dapat mengembangkan berbagai potensi dan kemampuannya dalam aspek kepemimpinan dalam mengelola sumber daya sekolah sesuai dengan kemampuan dan kebutuhannya. Sumber daya sekolah yang sangat penting dalam mengembangkan mutu sekolah adalah guru, dimana seorang guru memiliki tugas dan peran yang sangat besar untuk mengoptimalkan potensi yang dimiliki oleh peserta didik.

Kinerja guru adalah sesuatu sangat penting dalam pencapaian tujuan sekolah. Sekolah harus mengarahkan dan membina pendidik agar mereka mempunyai kinerja yang maksimal dalam menjalankan kewajibannya terutama dalam pelaksanaan tugas pokok dan fungsi sebagai guru (Andriani et al., 2018; Renata et al., 2018; Kristiawan dan Rahmat, 2018; Hasanah dan Kristiawan, 2019).

Menurut Maryan et al., (2020), kemampuan guru dalam melaksanakan kewajibannya sebagai seorang pendidik. Kinerja guru berpengaruh langsung terhadap kualitas pendidikan setiap peserta didik. Semakin baik kinerja guru maka akan semakin baik kualitas pendidikan yang dihasilkan. Artinya, apabila guru mempunyai kinerja yang baik maka hasil proses belajar mengajar juga akan baik. Untuk itu kinerja memegang peranan penting dalam pencapaian tujuan pengajaran yang optimal. Mengingat pentingnya peranan kinerja ini maka sekolah perlu meningkatkan kinerja guru agar tujuan pengajaran dapat tercapai secara maksimal.

Menurut Heidjracman dan Husnan dalam Sinambela (2016) mengatakan disiplin adalah setiap perseorangan atau kelompok yang menjamin adanya kepatuhan terhadap perintah dan berinisiatip untuk melakukan suatu tindakan yang diperlukan walaupun tidak ada perintah. Menurut Umami et al., (2020) motivasi kerja diartikan sebagai kekuatan yang mendorong seseorang melakukan sesuatu untuk mencapai tujuan yang diinginkan.

Kecamatan Penukal memiliki 21 Sekolah Dasar Negeri yang tersebar di 13 di wilayah Kabupaten Penukal Abab Lematang Ilir Provinsi Sumatra Selatan. Bedasarkan praobservasi yang dilakukan di Kantor Korwil Kecamatan Penukal, terdapat beberapa masalah yang ditemui diantaranya: (1) disiplin kepala sekolah yang belum optimal,terlihat dari tingkat absensi Kepala sekolah yang masih sangat rendah; (2) kurangnya motivasi kerja guru baik dari diri sendiri maupun dari luar dirinya, ini terbukti dalam menggunakan metode pembelajaran yang tidak bervariasi mengakibatkan siswa menjadi malas atau bosan dalam mengikuti pembelajaran; (3) pola pikir yang mengaggap bahwa datang terlambat bukanlah suatu pelanggaran peraturan sehingga mengakibatkan rendahnya kualitas kinerja guru. 
Terlebih lagi pada pertengahan bulan Maret 2020 ini negeri kita Indonesia juga terserang wabah yang membunuh dan penyebaranya sangat cepat, yang dikenal dengan nama pandemi Covid-19. Hal ini lebih memicu rendahnya tingkat kinerja kepala sekolah terlebih lagi guru, ini disebabkan karena pembelajaran yg diterapkan dengan cara daring, luring bahkan home visit, untuk melaksanakan pembelajaran dengan keadaan sekarang ini sangat banyak kendala yang dihadapi karena kemampuan guru, sarana dan prasarana di Kecamatan Penukal sangat minim, belum lagi di daerah yang jauh dari jangkauan signal sangat sulit untuk melakukan pembelajaran daring, hanya pembelajaran luring pilihannya dengan membebani tugas yang lebih berat kepada guru.

Berdasarkan uraian tersebut, diketahui bahwa kinerja dipengaruhi oleh beberapa faktor yaitu disiplin kerja kepala sekolah, dan motivasi kerja guru dan kemampuan guru. Penelitian ini bertujuan untuk menguji pengaruh disiplin kerja kepala sekolah (variabel X1), motivasi kerja (variabel X2) terhadap kinerja guru (varibel $Y$ ) serta pengaruh disiplin kerja kepala sekolah (variabel X1) dan motivasi kerja (variabel X2) secara bersama-sama terhadap kinerja guru guru (variabel Y).

\section{METODOLOGI}

Sasaran penelitian ini adalah 77 orang guru yang dijadikan sampel yang dipandang mampu mewakili seluruh guru se-Kecamatan Penukal. Jenis penelitian ini adalah deskripsi korelasional karena berusaha untuk memaparkan hubungan faktor-faktor atau sebagai variabel yang mempengaruhi keadaan tanpa memanipulasi variabel tersebut (Sugiyono, 2011). Pengambilan data menggunakan kuesioner atau angket. Objek penelitian dari kuesioner tersebut adalah guru Sekolah Dasar Negeri Se-Kecamatan Penukal.

Kuesioner yang dibagikan berisi pernyataan-pernyataan tentang disiplin kerja kepala sekolah, motivasi kerja, dan kinerja guru. Dalam kuesioner tersebut, guru diminta untuk mencentang atau memilih jawaban yang tersedia sesuai pendapatnya masingmasing. Alternatif jawaban dalam kuesioner penelitian ini terdiri dari 4 pilihan yaitu tidak pernah (TP), Kadang-Kadang (KK), Sering (SR) dan Selalu (SL).

\section{HASIL PEMBAHASAN}

Hasil analisis variabel gaya kepemimpinan menunjukkan bahwa ada $60,9 \%$ data berkategori cukup 39,1\% berkategori baik, sehingga dapat disimpulkan bahwa data distribusi gaya kepemimpinan kepala sekolah berkategori cukup dengan rata-rata skor $62,39 \%$. Deskripsi data dari tabel frekuensi kinerja guru tersebut adalah dilihat dari indikator variabel kinerja guru yaitu merencanakan program pembelajaran, melaksanakan program pembelajaran, dan mengevaluasi hasil proses pembelajaran. Dengan demikian, diketahui bahwa kinerja guru berdasarkan tabel distribusi tersebut berkategori baik sebanyak 92,8 \% sedangkan sisanya 7,2\% berkategori sangat baik. Jadi dapat disimpulkan interval skor variabel kinerja guru rata 81,51.

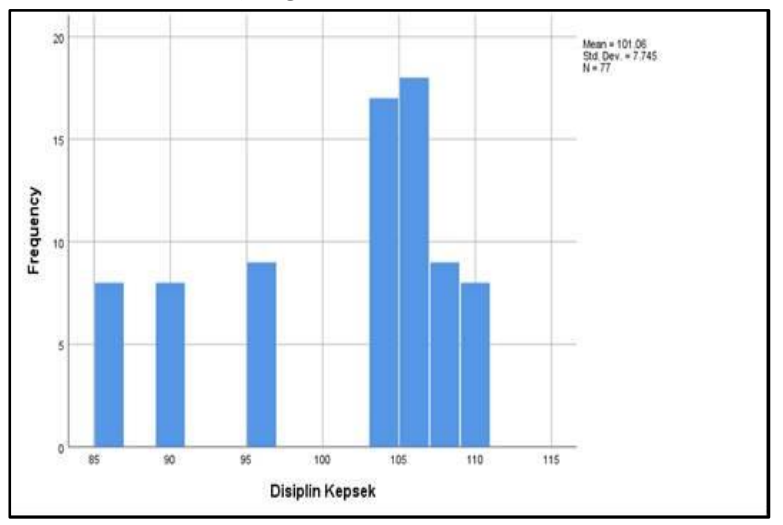

Gambar 1. Hasil Persepsi Disiplin Kepala Sekolah

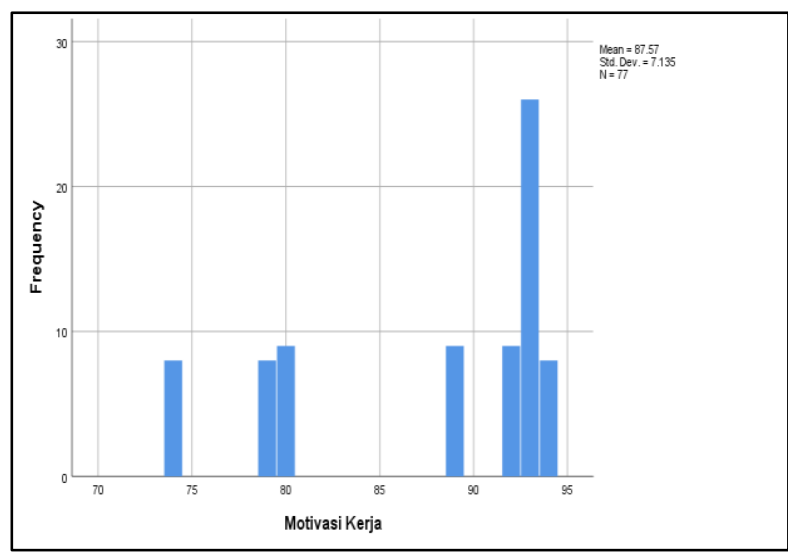

Gambar 2. Hasil Persepsi Motivasi Kerja Kepala Sekolah 
Hasil analisis variabel motivasi kerja menunjukkan bahwa sebanyak 8,1 \% berkategori baik, serta berkategori sangat baik sebanyak 91,9 \%, sehingga dapat disimpulkan bahwa data distribusi gaya kepemimpinan kepala sekolah berkategori sangat baik dengan skor rata-rata $77,65 \%$.

\section{Tes Normalitas}

Uji Normalitas diterapkan pada sampel terlebih dahulu sebelum pengujian hipotesis. Uji normalitas digunakan untuk menentukan apakah data variabel yang kita miliki memiliki distribusi normal atau tidak. Uji normalitas dilakukan menggunakan aplikasi SPSS versi 25 dengan menggunakan tes One-Sample Kolmogrov-Smirnov. Suatu data dikatakan berdistribusi normal apabila nilai signifikansi (p) > 0,05. Setelah dilakukan tes normalitas menggunakan uji Kolmogrov-Smirnov, nilai signifikansi (p) untuk variabel terikat disiplin kepsek (X1) adalah 0,084. Nilai signifikansi (p) untuk variabel terikat motivasi kerja (X2) adalah 0,133 . Terakhir, nilai signifikansi (p) untuk variabel bebas kinerja guru $(\mathrm{Y})$ adalah 0,124 . Selanjutnya, karena nilai signifikansi ketiga variabel tersebut $>0,05$, maka dapat dikatakan bahwa ketiga variabel tersebut berdistribusi normal.

Tabel 1. Hasil Uji Normalitas

\begin{tabular}{|c|c|c|c|c|}
\hline & & Disiplin Kepsek & Motivasi Keria & Kineria Guru \\
\hline $\bar{N}$ & & 77 & 77 & 77 \\
\hline \multirow[t]{2}{*}{ Normal Parameters ${ }^{\mathrm{ab}}$} & Mean & 101.06 & 87.57 & 105.82 \\
\hline & Std. Deviation & 7.745 & 7.135 & 8.279 \\
\hline \multirow[t]{3}{*}{ Most Extreme Differences } & Absolute & .274 & .291 & .194 \\
\hline & Positive & .131 & .184 & .194 \\
\hline & Neqaative & -274 & -291 & -189 \\
\hline Test Statistic & & 274 & 291 & .194 \\
\hline Asymp. Sig. (2-tailed) & & $.084^{3}$ & $.133^{\mathrm{a}}$ & $.124^{3}$ \\
\hline
\end{tabular}

\section{Tes Homogenitas}

Uji homogenitas adalah pengujian mengenai sama tidaknya variansi-variansi dua buah distribusi atau lebih. Uji homogenitas hanya digunakan untuk menguji perbedaan antara kedua kelompok atau lebih yang berbeda subjeknya atau sumber datanya. Oleh karena itu, uji homogenitas diperlukan sebagai asumsi dari uji t dan uji anova. Uji homogenitas pada data penelitian ini dilakukan menggunakan aplikasi SPSS versi 25. Suatu kelompok data dikatakan memiliki varians yang sama (homogen) apabila nilai signifikansi $(p)>0,05$. Setelah dilakukan uji homogenitas pada kelompok data variabel disiplin kepala sekolah (X1), motivasi kerja (X2), dan kinerja guru ( $Y$ ), didapatkan bahwa nilai signifikansi (p) nya adalah 0,214 . Karena nilai signifikansi $(p)=$ $0,214>0,05$, maka dapat dikatakan bahwa kelompok data tersebut homogen atau memiliki varians yang sama.

Tabel 2. Hasil Uji Homogenitas

\begin{tabular}{|c|c|c|c|c|c|}
\hline & & Levene Statistic & df1 & df2 & Sig. \\
\hline \multirow[t]{4}{*}{ Score } & Based on Mean & 1.229 & 2 & 228 & .295 \\
\hline & Based on Median & 2.195 & 2 & 228 & .114 \\
\hline & $\begin{array}{l}\text { Based on Median and with } \\
\text { adjusted df }\end{array}$ & 2.195 & 2 & 202.908 & .114 \\
\hline & Based on trimmed mean & 1.552 & 2 & 228 & 214 \\
\hline
\end{tabular}

\section{Pengujian Hipotesis}

Pengujian hipotesis dilakukan setelah uji prasyarat analis, yang pertama dilakukan adalah uji t dan uji F. Uji t dilakukan untuk menguji bagaimana pengaruh masingmasing variabel bebas secara individual terhadap variabel terikat. Uji t dapat dilakukan dengan melihat hasil nilai signifikansi atau nilai $t_{\text {hitung }}$. Ketetapan uji $\mathrm{t}$ adalah jika nilai sig. < 0.05, maka hipotesis $H_{a}$ diterima, artinya ada pengaruh variabel bebas terhadap variabel terikat. adalah jika nilai sig. $>0.05$, maka hipotesis $H_{o}$ diterima, artinya tidak ada pengaruh variabel bebas terhadap variabel terikat. Pada ketetapan nilai $t_{\text {hitung }}>$ $t_{\text {tabel }}$ maka hipotesis $H_{a}$ diterima, artinya ada pengaruh variabel bebas terhadap variabel terikat, jika nilai $t_{\text {hitung }}<t_{\text {tabel }}$ maka hipotesis $H_{o}$ diterima, artinya tidak ada pengaruh variabel bebas terhadap variabel terikat.

Uji $F$ dilakukan untuk mengetahui ketetapan model dan pengaruh variabel bebas secara bersama-sama terhadap varibel terikat, dalam hal ini antara variabel disiplin kepala sekolah dan variabel motivasi kerja secara bersama-sama terhadap kinerja guru. Ketetapan pengujian $\mathrm{F}$ adalah jika nilai sig. < 0.05, maka hipotesis $H_{a 3}$ diterima, artinya ada pengaruh variabel bebas secara bersama-sama terhadap variabel terikat. adalah jika nilai sig. > 0.05, maka hipotesis $\mathrm{H}_{o 3}$ diterima, artinya tidak ada pengaruh variabel bebas secara bersama-sama terhadap variabel terikat. Pada ketetapan nilai $F_{\text {hitung }}>F_{\text {tabel }}$ maka hipotesis $H_{a 3}$ diterima, artinya ada pengaruh variabel bebas secara bersama-sama terhadap 
variabel terikat, jika nilai $F_{\text {hitung }}<F_{\text {tabel }}$ maka hipotesis $H_{o 3}$ diterima, artinya tidak ada pengaruh variabel bebas secara bersamasama terhadap variabel terikat.

\section{Pengujian Hipotesis Pengaruh Disiplin keria Kepala Sekolah (X1) terhadap Kineria Guru $\underline{(Y)}$}

Nilai signifikansi variabel disiplin kepala sekolah terhadap kinerja guru adalah 0,003. Karena nilai signifikansi $0,003<0,05$, maka $\mathrm{Ha}_{1}$ diterima, artinya terdapat pengaruh signifikan dari variabel bebas disiplin kepala sekolah (X1) terhadap variabel terikat kinerja guru $(\mathrm{Y})$. Nilai adjusted $R$ square $=0,032$, artinya terdapat pengaruh sebesar $3,2 \%$ dari variabel bebas disiplin kepala sekolah terhadap variabel terikat kinerja guru.

\section{Penguiian Hipotesis Pengaruh Motivasi Kerja (X2) terhadap Kinerja Guru (Y)}

Nilai signifikansi variabel motivasi kerja terhadap kinerja guru adalah 0,000. Karena nilai signifikansi $0,000<0,05$, maka $H_{a 2}$ diterima. Artinya terdapat pengaruh signifikan dari variabel bebas motivasi kerja terhadap variabel terikat kinerja guru. Nilai adjusted $R$ square $=0,299$. Hal tersebut berarti terdapat pengaruh dari variabel bebas motivasi kerja (X2) terhadap variabel terikat kinerja guru $(Y)$ sebesar $29,9 \%$.

\section{Penguiian Hipotesis Disiplin Kepala} Sekolah (X1) dan Motivasi Kerja (X2) secara Simultan terhadap Kinerja Guru $(Y)$

Untuk mengetahui ada atau tidaknya pengaruh kedua variabel bebas disiplin kepala sekolah $\left(X_{1}\right)$ dan motivasi kerja $\left(X_{2}\right)$ secara bersamaan terhadap variabel terikat kinerja guru (Y), maka dilakukan uji F. Hasil dari uji $F$ dapat dilhat di tabbel berikut.

Tabel 3. Hasil Uji ANOVA

\begin{tabular}{|c|c|c|c|c|c|c|}
\hline \multirow[b]{2}{*}{ Model } & \multicolumn{6}{|c|}{ ANOVA $^{\mathrm{a}}$} \\
\hline & & Sum of Squares & Df & Mean Square & $\mathrm{F}$ & Sig. \\
\hline 1 & Regression & 2023.584 & 2 & 1011.792 & 23.501 & $.000^{6}$ \\
\hline & Residual & 3185.870 & 74 & 43.052 & & \\
\hline & Total & 5209.455 & 76 & & & \\
\hline
\end{tabular}

Dari hasil tabel tersebut, dapat dilihat bahwa nilai signifikansi adalah 0,000 . Karena nilai signifikansi $0,000<0,05$, maka dapat disimpulkan bahwa $H_{a 3}$ diterima, artinya ada pengaruh signifikan dari variabel bebas disiplin kerja kepala sekolah (X1) dan motivasi kerja (X2) secara bersama-sama terhadap variabel terikat kinerja guru (Y). Koefisien determinasi dapat dilakukan jika ada pengaruh secara simultan antara variabel bebas terhadap variabel terikatnya.. Adapun koefisien determinasi penelitian ini sebagai berikut.

Tabel 4. Hasil Koefisien Determinasi Model Summary

\begin{tabular}{|c|c|c|c|c|}
\hline Model & $R$ & R Square & Adjusted R Square & $\begin{array}{l}\text { Std. Error of the } \\
\text { Estimate }\end{array}$ \\
\hline 1 & $.623^{\mathrm{a}}$ & .388 & .372 & 6.561 \\
\hline
\end{tabular}

Menurut tabel tersebut, diketahui nilai adjusted $R$ square $=0,372$. Artinya terdapat pengaruh sebesar $37,2 \%$ dari variabel bebas disiplin kepala sekolah (X1) dan motivasi kerja (X2) secara bersama-sama terhadap variabel terikat kinerja guru $(Y)$. Setelah melakukan pengujian hipotesis dengan uji regresi ganda, hasil penelitian ini menunjukan bahwa terdapat pengaruh signifikan dari variabel bebas disiplin kepala sekolah (X1) terhadap variabel terikat kinerja guru $(Y)$ sebesar $3,2 \%$, Hasil penelitian dari pengaruh variabel bebas secara bersamasama terhadap variabel terikat, menunjukan bahwa variabel disiplin kepala sekolah kepala sekolah terhadap variabel kinerja guru sebesar 7,7\%.

Variabel bebas motivasi kerja (X2) terhadap variabel terikat kinerja guru $(Y)$ sebesar $29,9 \%$, dan variabel motivasi kerja guru terhadap variabel kinerja guru sebesar $90,5 \%$, artinya variabel motivasi kerja mempunyai pengaruh yang dominan terhadap variabel kinerja guru. Variabel bebas disiplin kepala sekolah (X1) dan variabel bebas motivasi kerja (X2) secara bersamaan terhadap variabel terikat kinerja guru (Y) sebesar 37,2\%. Untuk pengaruh variabel disiplin kepala sekolah dan variabel motivasi kerja secara bersama-sama terhadap variabel kinerja guru sebesar $98,3 \%$, nilai tersebut mengandung makna bahwa variabel disiplin kepala sekolah dan variabel motivasi kerja secara bersama-sama berpengaruh terhadap variabel kinerja guru sebesar 98,3\%, sedangkan sisanya dipengaruhi oleh variabel yang tidak diteliti. 
Hasil ini menunjukkan bahwa terdapat pengaruh variabel disiplin kerja kepala sekolah dan variabel motivasi kerja terhadap variabel kinerja guru baik secara individu maupun bersama-sama.

\section{KESIMPULAN}

Disiplin kepala sekolah berpengaruh terhadap kinerja guru SD Negeri seKecamatan Penukal. Hal ini berarti semakin tinggi disiplin kepala sekolah, maka kinerja guru semakin baik pula. Sebaliknya, semakin rendah disiplin kepala sekolah maka kinerja guru semakin kurang baik. Motivasi kerja guru berpengaruh terhadap kinerja guru SD Negeri se-Kecamatan Penukal. Hal ini berarti semakin motivasi kerja guru tinggi maka kinerja guru semakin baik pula.Sebaliknya semakin rendah motivasi kerja guru maka kinerja guru semakin kurang baik. Terdapat pengaruh yang simultan disiplin kepala sekolah dan motivasi kerja terhadap kinerja guru SD Negeri se-Kecamatan Penukal. Hal ini berarti semakin tinggi disiplin kepala sekolah dan motivasi kerja guru maka kinerja guru semakin baik pula. Sebaliknya, semakin rendah disiplin dan motivasi kerja guru maka kinerja guru semakin kurang baik.

\section{DAFTAR PUSTAKA}

Andriani, S., Kesumawati, N., \& Kristiawan, M. (2018). The Influence of the Transformational Leadership and Work Motivation on Teachers Performance. International Journal of Scientific \& Technology Research, 7(7).

Hayati, R., Arafat, Y., \& Sari, A. P. (2020). Pengaruh Komitmen Organisasi Dan
Motivasi Kerja Terhadap Kinerja Guru. JMKSP (Jurnal Manajemen, Kepemimpinan, dan Supervisi Pendidikan), 5(2).

Juniarti, E., Ahyani, N., \& Ardiansyah, A. (2020). Pengaruh Kepemimpinan Kepala Sekolah dan Disiplin Guru terhadap Kinerja Guru. Journal of Education Research, 1(3),193-199.

Maryani, A., Lian, B., \& Wardarita, R. (2020). Pengaruh Gaya Kepemimpinan Kepala Sekolah dan Budaya Organisasi Sekolah terhadap Kinerja Guru. Journal of Innovation in Teaching and Instructional Media, 1(1), 18-25.

Mulyasa, H.E. (2011). Manajemen dan Kepemimpinan Kepala Sekolah. Jakarta:Bumi Aksara.

Rohiat. (2019). Manajemen Sekolah. Bandung: Refika aditama

Sinambela. Lijan Poltak. (2016). Manajemen Sumber Daya Manusia: Membangun Tim Kerja yang Solid untuk Meningkatkan Kinerja, Jakarta: Bumi Aksara.

Sugiyono. (2011). Metode Penelitian Kuantitatif, Kualitatif, dan R\&D. Bandung: Alfabeta.

Umami, S., B. Lian, \& Missriani, (2020). Pengaruh Kepemimpinan dan Motivasi Kerja Guru Terhadap Disiplin Kerja. JMKSP (Jurnal Manajemen, Kepemimpinan, dan Supervisi Pendidikan), 6(1), 52-66. 